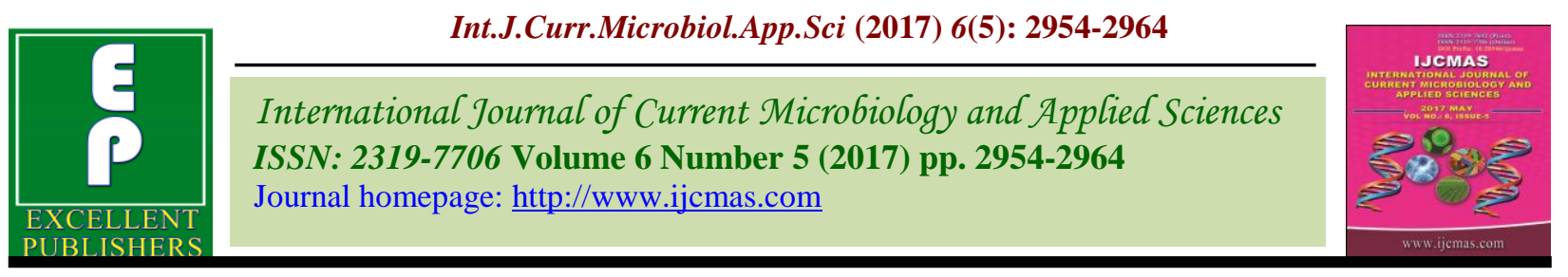

Original Research Article

https://doi.org/10.20546/ijcmas.2017.605.334

\title{
Pseudomonas aeruginosa KPSE 3 - An Endophytic PGPR for Bio Control of Potato Phytopathogens
}

\author{
H.A. Pandya* and H.N. Shelat \\ Department of Microbiology, B. A. College of Agriculture, Anand Agricultural University, \\ Anand (Gujarat), India \\ *Corresponding author
}

\section{A B S T R A C T}

Keywords

Endophytic,

Siderophore,

Phytopathogen,

Eco-friendly.

Article Info

Accepted:

26 April 2017

Available Online:

10 May 2017
Endophytic bacteria residing within the living plant tissue without causing harm to it have promise to be practically used in agriculture and included as active components of Integrated Disease Management (IDM). In present study 4 strains of pseudomonad were isolated from surface sterilized plant parts viz. leaf, root, tuber and stem of potato (Solanum tuberosum L. $c v$. Kufri Badshah) by using King's B agar and preliminary characterized as Pseudomonas on the basis of morphological and biochemical characteristics. Among all the isolates KPSE3 was emerged as best PGP strain showing production of siderophore and IAA (9.79 $\mu \mathrm{g} / \mathrm{ml})$. Moreover, KPSE3 has capacity of nitrogen fixation $(23.57 \mathrm{mg} \mathrm{N} / \mathrm{g}$ glucose consumed) and phosphate solubilization $(21.20 \mathrm{P} \mu \mathrm{g} / \mathrm{ml}$ at $3 \mathrm{DAI})$. The isolate KPSE3 also have broad spectrum antifungal activity with $15 \%$ growth inhibition of Pythium sp. 34\% of Fusarium sp. and $40 \%$ of Macrophomina sp. In pot trial conditions potato tuber bacterization with KPSE3 in presence of phytopathogens viz. Fusarium sp., Macrophomina sp. and pythium sp., significantly influenced growth of Potato $c v$. Kufri Badshah. The endophytic isolate KPSE3 exhibiting the best PGP activity was further characterized at molecular level and identified as Pseudomonas aeruginosa (Gene Bank Accessions Number- KC787580) which can be used for developing a cost effective eco-friendly multifunctional biofertilizer and biocontrol agent for sustainable agriculture.

\section{Introduction}

Phytopathogenic fungi are the most visible threats for sustainable food production, their control can be achieved by either chemicals or biological measures. Over use of chemicals may cause soil, water and air pollution as well as have harmful effects on human beings and living organisms. Due to increasing awareness among consumers about food safety, scientists are in search of alternative biological control that lowers down the use of chemicals in agriculture (Gerhadson, 2002). Biological control of plant diseases involving the use of antagonistic microorganisms offers an excellent alternative to chemical control. Pseudomonads have special mechanisms for inhibition of pathogenic fungi by various 
mode of action like production of antibiotics, iron chelating compound like siderophroes (Meyer, 2000), hydrolytic enzyme and biosurfactants (Nielsen et al., 2002). Competition for favorable nutritional sites (Suslow and Schroth, 1982) $\beta$-(1,3)-glucanase and chitinase (Renwick et al., 1991) and cyanide (Flaishman et al., 1996) induction of systemic resistance (Parmar and Dadarwala, 1999) and ability to effectively colonize roots is responsible for plant growth promotion (Defago and Duffy, 1999). Keeping this in mind, the main goal of the current study was to look for the best endophytic plant growth promoting bio-agents which could be applied to the potato to get a higher yield and also work as biocontrol against soil borne pathogen like Fusarium sp., Macrophomina sp. and Pythium sp.

In the present study, an attempt has been made to isolate endophytic bacteria mainly belonging to Pseudomonas genus from potato possessing ability to work as plant growth promoting bacteria (PGPB) as well as biocontrol agent.

\section{Materials and Methods}

\section{Isolation of endophytic Pseudomonas from potato}

In present study, isolation of endophytic pseudomonads was attempted from various plant parts (root, leaf, stem and tuber) of potato (Solanum tuberosum L.) $c v$. Kufri Badshah. For isolation potato plant samples were surface sterilized and inoculated in to King's B medium and plates were incubated at $37^{\circ} \mathrm{C}$ for 48 to $72 \mathrm{~h}$.

\section{Characterization of isolates}

Isolates were characterized on the basis of morphological, cultural and biochemical characteristics (Halt et al., 1994).

\section{Antagonistic effect on pathogenic fungi (Biocontrol)}

The antagonistic activity of isolates against Fusarium sp., Macrophomina sp. and Pythium sp. was tested by dual culture technique. The radial growth of mycelium was measured and per cent inhibition (PI) was calculated as follows.

Per cent inhibition $(\mathrm{PI})=\frac{\mathrm{C}-\mathrm{T}}{\mathrm{C} \times 100}$

Where, C- mycelial growth of pathogen in control and T-mycelial growth of pathogen in dual plate.

\section{In vivo inhibitory activity of isolates}

Small sized potato tubers surface sterilized and injected with $100 \mu \mathrm{l}$ of bacterial isolate suspension $\left(10^{7}\right.$ bacterial cells $\left./ \mathrm{ml}\right)$ at one corner and Fusarium sp. was inoculated after $24 \mathrm{~h}$ at same corner and each treatment was repeated three times. Inoculated tubers were kept in growth chamber at $25-27^{\circ} \mathrm{C}$ for 21 days at $70 \%$ RH. After incubation period, tubers were cut longitudinally from the sites of inoculation and dry rot induced maximal width (W) and depth (d) was noted. The pathogen penetration in to tubers was calculated using formula Penetration $(\mathrm{mm})=$ $(\mathrm{w} / 2+(\mathrm{d}-6)) / 2($ Lapwood et al., 1984)

PGP traits of endophytic isolates viz. $\mathrm{N}$ fixation, $P$ Solubilization, IAA and Siderophore production

\section{Nitrogen fixing capacity}

For detection of nitrogen fixing capacity of isolates the bacterial cultures were inoculated in nitrogen free media containing glucose as carbon source. Inoculated media were incubated at $28 \pm 2^{\circ} \mathrm{C}$ for one week and nitrogen fixation rates were measured by 
Micro-Kjeldahl method (A.O.A.C., 1965) and sugar utilization was estimated by Fehling's method. The rate of nitrogen fixation was expressed as $\mathrm{mg}$ nitrogen fixed/gram of glucose consumed.

Phosphate solubilizing efficiency of endophytic bacteria

Isolates were tested for their phosphate solubilizing capacity in PKVK Medium. Here, PKVK broth was inoculated with 100 $\mu \mathrm{l}$ bacterial culture and soluble phosphate content was estimated as per the method given by APHA, 1995 at 3 and 5 days after inoculation.

\section{Estimation of growth hormone IAA}

Isolates were grown in respective medium with $0.1 \%$ tryptophan and incubated at a $28 \pm$ $2^{\circ} \mathrm{C}$ temperature during $24 \mathrm{~h}$ on a rotary shaker $(90 \mathrm{rpm})$, after that they were centrifuged at $5000 \mathrm{rpm}$ for $25 \mathrm{~min}$. The supernatant liquid mixed with Salkowski's reagent (1:2) and the colors were measured by spectroscopy at $530 \mathrm{~nm}$ after $30 \mathrm{~min}$. The levels of IAA production were estimated by a standard IAA graph.

\section{Detection of siderophore}

Detection of siderophore producing organism was carried out by using the method as described and recorded by Schwyn and Neilands (1987).

\section{Efficacy of proven endophytic isolates against Phytopathogenic fungi in potato}

In pot experiment the best proven Pseudomonas isolate was tested for antifungal activity against soil borne fungi viz. Fusarium sp., Macrophomina sp. and Pythium sp. following completely randomized design with eight treatments viz. $\mathrm{T}_{1}$ : Uninoculated control,
$\mathrm{T}_{2}$ : isolate (seed tuber bacterization @ 5 $\mathrm{ml} / \mathrm{kg}$ seed), $\mathrm{T}_{3}$ : isolate + Fusarium sp., $\mathrm{T}_{4}$ : isolate + Macrophomina sp., $\mathrm{T}_{5}$ : isolate + Pythium sp., $\mathrm{T}_{6}$ : Fusarium sp., $\mathrm{T}_{7}$ : Macrophomina sp. and $\mathrm{T}_{8}$ : Pythium sp. each with three replications.

\section{Results and Discussion}

Isolation of microorganisms, screening for desirable traits and selection of efficient strains are important steps to optimize high crop yields and improve the sustainability of the ecosystem controlling plant pathogen. Endophytic bacteria are one of the most potential biological control agents for plant disease management. The aim of this work is to evaluate the antimicrobial activities of endophytic bacteria isolated from potato (Solanum tuberosum L.) and to check their plant growth promoting ability as well as in vitro and in vivo efficacy for antagonistic characters.

\section{Isolation of endophytic pseudomonads}

Plant is the prime source of nutrition for microorganisms in soil providing them nutrients indirectly from root exudates or dead tissues or directly when microorganisms colonize the interior of plant roots or other organs. In this study, after 2-3 days of the inoculation due to limitation of nutrients inside plant part, microorganisms ooze outside the plant part and grow luxuriously in the selective medium.

KPSE1-KPSE4 gave shiny colony appearance and all isolates produced yellow-green diffusible pigment of variable intensities on King's B medium. These observations are supported by findings of Kuarabachew et al., 2007 who isolated Pseudomonas spp. from soil samples collected from potato growing areas around Wolyata, Shahamane and Wonodogenet, Ethiopian. Moreover, all the 
growth patterns were confirmed keeping standard strains Pseudomonas fluroscens as check.

\section{Morphological characterization}

The colonies of the four isolates (KPSE1KPSE4) were irregular, undulate, convex, smooth and slimy, transparent and characteristic smell on $\mathrm{KB}$ plate. Isolates produced yellow-green diffusible pigment of variable intensities on King's B medium. The cells of all the four isolates were $\mathrm{G}$-ve, rods, which is characteristic feature of genus Pseudomonas.

\section{Biochemical characterization}

Results of carbohydrate utilization pattern of all isolates are presented in Table 1. Isolates KPSE1-KPSE4 can utilize almost all the tested sugars viz. D-glucose, ribose, mannitol, lactose, sucrose, inositol, maltose, arabinose, raffinose, galactose, cellobiose, fructose and xylose. Kuarabachew et al., 2007 reported $P$. fluorescens utilized arabinose, galactose, glucose, fructose, mannose, trehalose. The data revealed that all the tested isolates were positive for catalase, indole production and negative for $\mathrm{H}_{2} \mathrm{~S}$ production, while all the isolates are positive for gelatinase and urease (Table 1).

Sakthivel and Karthikeyan (2012) studied 30 bacterial isolates obtained from Coleus forskohlii rhizospheric soil of Perambalur and Salem districts in Tamil Nadu and discriminated isolates in different genus as Azospirillum spp., Bacillus spp., Pseudomonas spp., and Azotobacter spp. on the basis of biochemical characterization. All the biochemical tests for characterization of endophytic bacterial isolates have well established similarities of KPSE1-KPSE4 with genus Pseudomonas.
PGP traits of endophytic isolates viz. $\mathbf{N}$ fixation, $P$ solubilization, IAA and siderophore production

\section{Nitrogen fixing capacity}

Comparison of endophytic diazotrophic bacteria with free living nitrogen fixers showed that internalized bacteria are much more likely to contribute significantly to nitrogen economy of the plant (Cocking, 2003) (Table 2).

In vitro nitrogen fixation efficiency of isolates showed that all the isolates were confirmed to have ability of fix atmospheric nitrogen. It was revealed from the result that nitrogen fixing potentiality of these isolates ranged from $11.23-23.57 \mathrm{mg} \mathrm{N} / \mathrm{g}$ of glucose consumed and isolate KPSE-3 was showing maximum nitrogen fixation capacity among all the isolates $(23.57 \mathrm{mg} \mathrm{N} / \mathrm{g}$ of glucose consumed). Akond et al., 2007 studied Azotobacter isolates recovered from wheat fields among them highest amount of $\mathrm{N}$ was found to be fixed by the isolate M1 $(9.26 \mathrm{mg}$ $\mathrm{N} / \mathrm{g}$ substrate) and the lowest by the isolate M4 (5.45 mg N/g substrate).

\section{Phosphate solubilization efficiency of endophytic isolates}

Estimation of $\mathrm{P}$ in the PKVK broth revealed that all the strains released $\mathrm{P}$ from tri calcium phosphate (TCP). Isolates KPSE3 recorded maximum available phosphate $21.20 \mathrm{P} \mu \mathrm{g} / \mathrm{ml}$ at 3 DAI, whereas, all isolates that reduce the phosphates solubilization after 5 DAI compare to 3 DAI because of utilization of solubilized phosphate by microorganisms. The present findings established the phosphate solubilization as an additional benefit of endophytic bacterial isolates, apart from fixing atmospheric nitrogen all the isolates can also improve the availability of phosphorous in crop's rhizosphere. 


\section{Estimation of growth hormone IAA}

Data regarding IAA production of isolates are presented in Table 2. All tested isolates grown in a culture medium contain tryptophan as carbon source. IAA production was detected by the Salkowski reagent under spectrophotometer in the range of $1.07 \mu \mathrm{g} / \mathrm{ml}$ to $9.79 \mu \mathrm{g} / \mathrm{ml}$ IAA. The higher concentration of IAA was obtained by KPSE3 strain 9.79 $\mu \mathrm{g} / \mathrm{ml}$.

Similarly Pedraza et al., (2004) found that Azospirillum strains produced the highest concentrations of IAA (16.5-38 $\mu \mathrm{g}$ IAA/mg protein) whereas, Gluconacetobacter and $P$. stutzeri strains produced lower concentrations of IAA ranging from 1-2.9 $\mu \mathrm{g}$ IAA/mg protein in a culture medium supplemented with tryptophan.

\section{Detection of siderophore}

Isolates KPSE1-KPSE4 were found positive for siderophore production. Similarly, Dave and Dube (2000) isolated six rhizobacterial $P$. fluorescens on Chrom Azurol $\mathrm{S}$ agar medium. Among six isolates, two gave maximum siderophore production. Siderophore chelates iron and other metals contribute to disease suppression by conferring competitive advantages to biocontrol agents.

\section{Antagonistic effect on pathogenic fungi (Biocontrol)}

\section{In vivo inhibitory activity of isolates}

Out of 4 native endophytic Pseudomonas isolates, KPSE3 and KPSE4 showed inhibition of the phytopathogenic fungus Fusarium sp. (Figure. 1) compared with control. Results showed that isolates KPSE3 (2.22 $\mathrm{mm})$ showing minimum Penetration of Fusarium sp. compare with the control (5.9 mm) (Table 3).
Similar type of results was also reported by Remadi et al., (2006). They reported that bacillus application into sites of infection, 24 $\mathrm{h}$ before inoculation by pathogen, reduced dry rot and population of plant pathogenic fungi viz. F. oxysporum. F. graminearum, F. Solani in presence of an active host resistance by whole tuber assay.

\section{In vitro interaction of isolate}

All native endophytic Pseudomonas isolates were tested for antifungal activity against plant pathogenic fungi Pythium sp., Fusarium sp. and Macrophomina sp. by dual culture assay. After seven days incubation, fungal hyphae of phytopathogenic fungi were unable to reach the bacterial culture and inhibition zone was established with the dimension of inhibition circle, ranging from 5 to $40 \mathrm{~mm}$. Highest antifungal activity was recorded by isolate KPSE3 (40 \%) followed KPSE4 (10\%) against Macrophomina sp. Highest antifungal activity against Fusarium sp. was recorded for isolate KPSE3 (34\%) and the highest antifungal activity was recorded by isolate KPSE3 (15\%) against Pythium sp. Among all the tested isolates, KPSE3 found to have broad spectrum of antifungal activity against of Macrophomina sp. (40\%), Fusarium sp. (34\%) and Pythium sp. (15\%). So from antifungal activity results, the most promising culture KPSE3 was selected for bacterization in a replicated pot trial (Table 4). Similar type of results were recorded by Singh et al., 2008 they reported isolate $B$. subtilis BU 1 strongly inhibited growth of $M$. phaseolina with maximum inhibition of $74 \%$ at 5 DAI. They also reported inhibition of $F$. oxysporum and Pythium sp. by the same isolate. At the same time, Naik et al., (2008) reported antifungal potential of $P$. fluorescens isolate towards number of plant pathogenic fungi including $F$. oxysporum, $M$. phaseolina and reported that the fungal growth was inhibited with zone diameter of 10 and $36 \mathrm{~mm}$ (Table 4). 
Table.1 Characterization of native isolates

\begin{tabular}{|c|c|c|c|c|c|}
\hline $\begin{array}{l}\text { Sr } \\
\text { NO. }\end{array}$ & Test & KPSE 1 & KPSE 2 & KPSE 3 & KPSE 4 \\
\hline \multicolumn{6}{|c|}{ Morphological characteristics } \\
\hline 1 & Shape & Irregular & Round & Round & Round \\
\hline 2 & Margin & Undulate & Entire & Entire & Entire \\
\hline 3 & Elevation & Convex & Slightly raised & Slightly raised & Slightly raised \\
\hline 4 & Texture & $\begin{array}{l}\text { Smooth \& } \\
\text { slimy }\end{array}$ & Smooth & Smooth & Smooth \\
\hline 5 & Opacity & Transparent & Transparent & Transparent & Transparent \\
\hline 6 & $\begin{array}{l}\text { Microscopic } \\
\text { characterization }\end{array}$ & $\begin{array}{l}\text { Gram negative } \\
\text { short rod }\end{array}$ & $\begin{array}{l}\text { Gram negative } \\
\text { short rod }\end{array}$ & $\begin{array}{l}\text { Gram } \\
\text { negative short } \\
\text { rod }\end{array}$ & $\begin{array}{l}\text { Gram } \\
\text { negative short } \\
\text { rod }\end{array}$ \\
\hline \multicolumn{6}{|c|}{ Biochemical characteristics } \\
\hline 7 & Glucose & + & + & + & + \\
\hline 8 & Ribose & + & + & + & + \\
\hline 9 & Mannitol & + & + & + & + \\
\hline 10 & Lactose & + & + & + & + \\
\hline 11 & Inositol & + & + & + & + \\
\hline 12 & Maltose & + & + & + & + \\
\hline 13 & Arabionose & + & + & + & + \\
\hline 14 & Raffinose & + & + & + & + \\
\hline 15 & Galactose & + & + & + & + \\
\hline 16 & Cellobiose & + & + & + & + \\
\hline 17 & Fructose & + & + & + & + \\
\hline 18 & Xylose & + & + & + & + \\
\hline 19 & Sucrose & + & + & + & + \\
\hline 20 & Gelatinase & + & + & + & + \\
\hline 21 & Methyl red & - & - & - & - \\
\hline 22 & Urease & + & + & + & + \\
\hline 23 & Catalase & + & + & + & + \\
\hline 24 & Indole production & + & + & + & + \\
\hline 25 & Starch hydrolysis & - & - & - & - \\
\hline 26 & $\mathrm{H}_{2} \mathrm{~S}$ production & - & - & - & - \\
\hline
\end{tabular}


Table.2 PGPR traits of isolates

\begin{tabular}{|l|l|c|c|c|c|}
\hline \multirow{2}{*}{ No. } & \multirow{2}{*}{$\begin{array}{c}\text { Isolate } \\
\text { No. }\end{array}$} & N fixation & \multicolumn{2}{|c|}{ P solubilization } & $\begin{array}{c}\text { IAA } \\
\text { production }\end{array}$ \\
\cline { 3 - 6 } & $\begin{array}{c}\mathbf{m g} \mathbf{N} / \mathbf{g} \text { of glucose } \\
\text { consumed }\end{array}$ & $\begin{array}{c}\mathbf{P} \boldsymbol{\mu \mathbf { g }} / \mathbf{m l} \\
\mathbf{3} \mathbf{D A I}\end{array}$ & $\begin{array}{c}\mathbf{P} \boldsymbol{\mu g} / \mathbf{m l} \\
\mathbf{5} \mathbf{D A I}\end{array}$ & $\boldsymbol{\mu g} / \mathbf{m l}$ \\
\hline 1 & KPSE1 & 14.33 & 10.2 & 5.8 & 6.07 \\
\hline 2 & KPSE2 & 13.60 & 12.7 & 8.0 & 4.92 \\
\hline 3 & KPSE3 & 23.57 & 21.2 & 17 & 9.79 \\
\hline 4 & KPSE4 & 11.23 & 15 & 5.0 & 1.07 \\
\hline
\end{tabular}

Table.3 In vivo effect of endophytic isolates on Fusarium sp. causing potato dry rot

\begin{tabular}{|l|l|c|}
\hline Sr. No. & Isolate No. & $\begin{array}{c}\text { mean radial growth } \\
(\text { Penetration(mm)) }\end{array}$ \\
\hline 1. & KPSE3 & 2.2 \\
\hline 2. & KPSE4 & 4.8 \\
\hline 3. & Control & 5.9 \\
\hline
\end{tabular}

Table.4 In vitro biological control potential of native endophytic isolates against phytopathogenic fungi

\begin{tabular}{|l|l|c|c|c|}
\hline Sr. No. & Name of isolate & $\begin{array}{c}\text { Fusarium sp. } \\
(\boldsymbol{\%})\end{array}$ & $\begin{array}{c}\text { Macrophomina sp. } \\
(\boldsymbol{\%})\end{array}$ & $\begin{array}{c}\text { Pythium sp. } \\
(\boldsymbol{\%})\end{array}$ \\
\hline 1. & KPSE3 & 34 & 40 & 15 \\
\hline 2. & KPSE4 & 29 & 10 & 0 \\
\hline
\end{tabular}

Table.5 Effect of bacterization with the best isolate KPSE3 in potato to control phytopathogenic fungi

\begin{tabular}{|c|l|c|c|c|c|c|}
\hline $\begin{array}{c}\text { Tr. } \\
\text { No. }\end{array}$ & Treatment & $\begin{array}{c}\text { Germination } \\
(\mathbf{\%})\end{array}$ & $\begin{array}{c}\text { 30 DAS } \\
\text { height } \\
(\mathbf{c m})\end{array}$ & $\begin{array}{c}\text { 60 DAS } \\
\text { height } \\
(\mathbf{c m})\end{array}$ & $\begin{array}{c}\text { Fresh } \\
\text { biomass } \\
(\mathbf{g})\end{array}$ & $\begin{array}{c}\text { Dry } \\
\text { biomass } \\
(\mathbf{g})\end{array}$ \\
\hline T1 & Uninoculated Control & 87.50 & $15.37^{\mathrm{ab}}$ & $37.00^{\mathrm{ab}}$ & $39.25^{\mathrm{ab}}$ & $15.25^{\mathrm{b}}$ \\
\hline T2 & KPSE3 & 93.75 & $17.62^{\mathrm{a}}$ & $39.25^{\mathrm{a}}$ & $41.75^{\mathrm{a}}$ & $17.22^{\mathrm{a}}$ \\
\hline T3 & KPSE3+ Fusarium sp. & 87.50 & $15.22^{\mathrm{ab}}$ & $33.75^{\mathrm{cd}}$ & $35.70^{\mathrm{bc}}$ & $10.75^{\mathrm{c}}$ \\
\hline T4 & KPSE3+Macrophomina sp. & 81.25 & $14.50^{\mathrm{ab}}$ & $30.25^{\mathrm{e}}$ & $32.50^{\mathrm{cd}}$ & $12.00^{\mathrm{c}}$ \\
\hline T5 & KPSE3+Pythium sp. & 62.50 & $14.25^{\mathrm{ab}}$ & $35.00^{\mathrm{bc}}$ & $30.62^{\mathrm{d}}$ & $11.00^{\mathrm{c}}$ \\
\hline T6 & Fusarium sp. & 75.00 & $15.25^{\mathrm{ab}}$ & $32.00^{\mathrm{de}}$ & $21.50^{\mathrm{e}}$ & $8.00^{\mathrm{d}}$ \\
\hline T7 & Macrophomina sp. & 62.50 & $14.12^{\mathrm{ab}}$ & $27.75^{\mathrm{f}}$ & $25.00^{\mathrm{e}}$ & $6.50^{\mathrm{de}}$ \\
\hline T8 & Pythium sp. & 50.00 & $12.87^{\mathrm{b}}$ & $21.75^{\mathrm{g}}$ & $17.50^{\mathrm{f}}$ & $5.50^{\mathrm{e}}$ \\
\hline & S.Em & - & 1.28 & 0.74 & 1.17 & 0.52 \\
\hline & CD At 5 \% & - & 3.70 & 2.14 & 3.37 & 1.50 \\
\hline & C.V \% & 17.15 & 4.62 & 7.65 & 9.61 \\
\hline
\end{tabular}

Note: Treatment means with the letter/letters in common are not significant by Duncan's New Multiple Range Test at $5 \%$ level of significance 
Figure.1 Radial growth inhibition of Fusarium by isolate KPSE 3 and KPSE 4

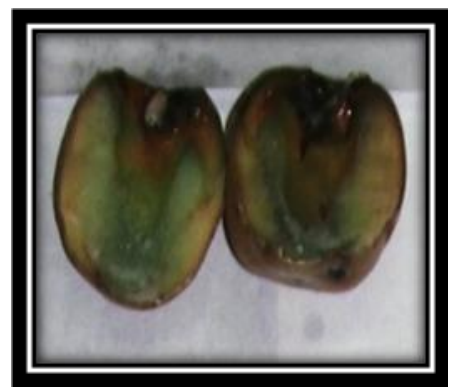

Control

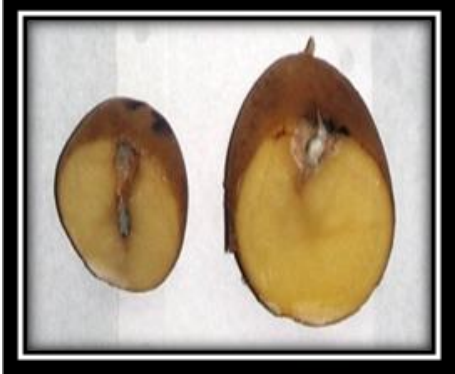

KPSE 3

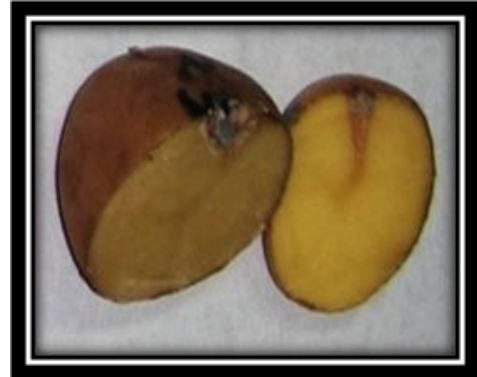

KPSE4

Figure.2 Phylogenetic tree of partial 16S rRNA genes of pseudomonas spp. KPSE3 isolate from closely related of bacteria obtained after BLAST

Azomonas agilis strin NCIB 11693165 ribosomal RNA, Dartial sequence

Pseudomonas pohangensis strin H3- R18 165 ribosomal RNA, partial sequence

Pseudomonas tuomuerensis strain 7\&-123 165 ribosomal RNA, Dartial sequence

49proteobacterial t leaves

$\rightarrow-4$ groteobacterial 3 leaves

6

Aproteobacterial 4 leaves

3 oproteobacterial 4 leaves

9 proteobacteria| 56 leaves

Q Pseudomonas alcaligenes strain LAM12411 165 ribosomal RNA, complete sequence

$\longrightarrow$ igproteobacterial 4 leaves

4 g.proteobacterial 6 leaves

9. proteobacterial 11 leaves

Pseudomonas otifidis strin MCC 10330165 ribosomal RNA, complete sequence

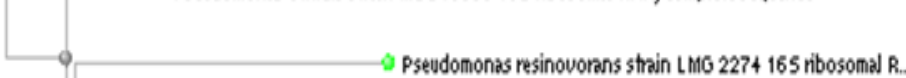

P. Pseudomonas aeruginosa strain DSM 50071165 ribosomal RNA, comp

Pseudomonas SDD KPSE-3

9

Pseudomonas aemginosa PA01 strin PA01 165 ribosomal RNA, complete sequence

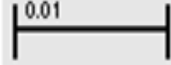


Figure.3 Pot efficacy of PGPB (KPSE3) in presence of pathogenic fungi on potato crop at $30 \mathrm{DAS}$
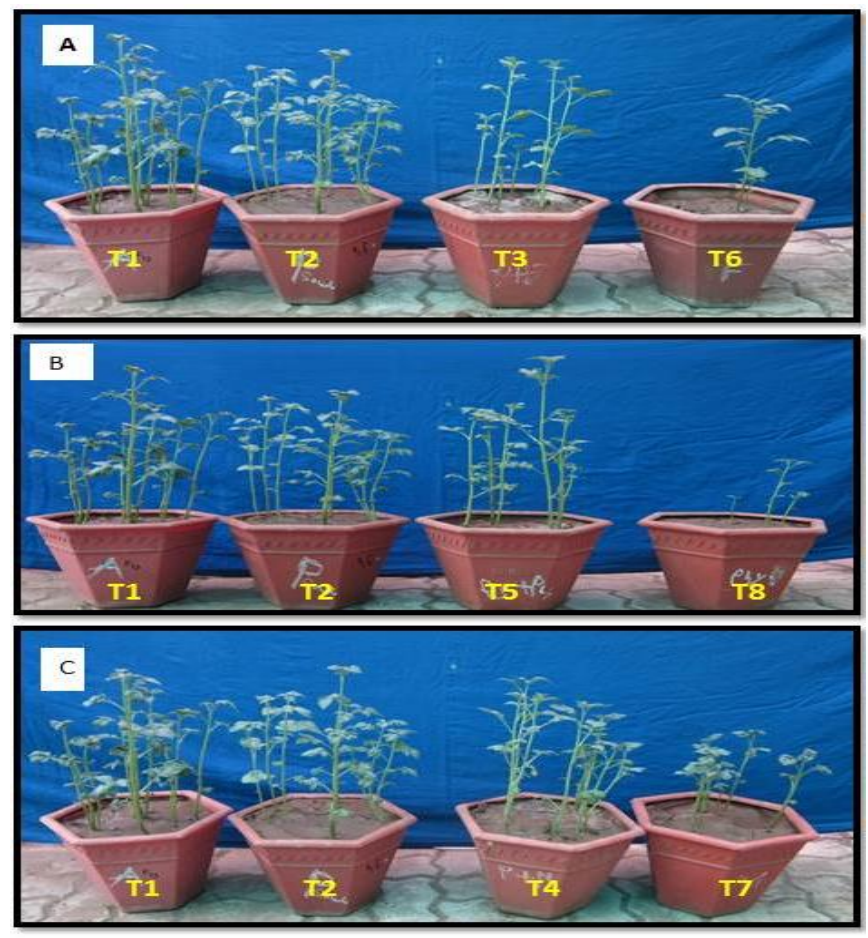

$16 \mathrm{~S} r \mathrm{RNA}$ gene sequencing and identification of native potential KPSE3 isolate

16S rRNA partial gene sequence identified isolate KPSE3 as Pseudomonas sp. with $100 \%$ similarity and $100 \%$ query coverage to Pseudomonas aeruginosa (GeneBank Accn. No: KC787580). Additionally, the phylogenetic position of the isolate was also worked out within the available database of NCBI (presented as phylogenetic tree in figure 4.4). The phylogenetic tree indicated that KPSE3 belong to Pseudomonas aeruginosa PAO1 $\mathrm{\gamma}$ - proteobacteria and grouped with other Pseudomonas sp. The tree formed two major group/clusters within available known $\mathrm{\gamma}$ - proteobacterial $\mathrm{sp}$. Isolate KPSE3 was placed in cluster one with more than $99 \%$ similarity with known Pseudomonas sp. indicating phylogenetic closeness (Figure 2).
Efficacy of proven endophytic isolate KPSE3 (P. aeruginosa) (GeneBank Accn. No: KC787580) against phytopathogenic fungi in potato

In pot experiment the best proven isolate KPSE3 was tested for antifungal activity against phytopathogenic fungi viz. Fusarium sp., Macrophomina sp. and Pythium sp.

A pot trial was carried out with recommended dose $(220 \mathrm{~kg} / \mathrm{ha}(\mathrm{RDN})+110 \mathrm{Kg} / \mathrm{ha}(\mathrm{RDP})$ $+220(\mathrm{RDK})$ ) to study the effect of endophytic bacterial isolate KPSE3 on Potato $c v$. Kufri Badshah and also to demonstrate plant protection aspect in potato due to bioinoculants.

It was observed from the pot experiment that KPSE3 treated plants were noticeably taller and had more fresh and dry weight (Table 5). 
Effect of endophytic isolates KPSE3 on potato plants germination per cent, plant height at 30 and 60 DAI, fresh and dry biomass

Results presented in table 5 indicted that treatment $\mathrm{T} 3$, T4, T5 receiving seed tuber inoculation of KPSE3 along with pathogenic fungi viz. Pythium sp., Fusarium sp. and Macrophomina sp. showed significant increase in germination per cent (Figure 3), plant height, fresh and dry biomass of potato as compared to treatment $\mathrm{T} 6, \mathrm{~T} 7, \mathrm{~T} 8$ pathogenic control.

Singh et al., 2010 reported that fluorescent $P$. aeruginosa PN1 increased plant germination percentage, shoot and root length, shoot and root fresh as well as dry weight compared to non- bacterized control in pot trial containing M. phaseolina-infested soil. PN1 exhibited strong antagonistic property against M. phaseolina, suppressed the disease in vitro.

\section{References}

A.O.A.C. (1965). Official methods of analysis of the association of official agricultural chemists. $10^{\text {th }}$ edn., 744-745.

Akond, M.A., S. Mubassara and M. M. Rahman (2007). Distribution and abundance of Azotobacter in wheat fields of bangladesh. Ban. J. Micro., 151-153.

APHA, (1995). Standard methods for the examination of water and wastewater, phosphates, edited by Eaton, AD, Clesceri, LS and Greenberg, AE, Published by American Public Health Association Washington DC 2005. Asea P. E. A. R. M. N.

Cocking, E.C. (2003). Endophytic colonization of plant roots by nitrogen fixing bacteria. Plant soil, 252: 169175.
Dave, B.P. and H. C. Dube (2000). Detection and chemical characterization of siderophore of rhizobacterial fluorescent Pseudomonas. Ind. Phytopath., 53: 97-98.

Defago, G. and B. K. Duffy (1999). Environmental factors modulating antibiotic and siderophore biosynthesis by Pseudomonas fluorescens biocontrol strains. App. Environ. Microbiol., 65:2429-2438.

Gerhadson, B. (2002). Biological substitute for pesticides. Trends Biotechnol., 8:338-343.

Kuarabachew, H., F. Assefa and Y. Hiskias (2007). Evaluation of ethiopian isolates of Pseudomonas fluorescens as biocontrol agent against potato bacterial wilt caused by Ralstonia (Pseudomonas) solanacearum. Acta. Agri. Slo., 90(2):125-135.

Lapwood, D.H., P. J. Read and J. Spokes (1984). Methods of assessing the susceptibility of potato tubers of different cultivars to rotting by Erwinia caratovora subsp. atroseptica and carotovora. Plant Pathol., 33:13-20.

Meyer, J.M. (2000). Pyoverdines: pigments, siderophores and potential taxonomic markers of fluorescent Pseudomonas species. Arch. Microbiol., 174:135-142.

Naik, P.R., G. Raman, K. B. Narayanan and N. Sakthivel (2008). Assessment of genetic and functional diversity of phosphate solubilizing fluorescent Pseudomonads isolated from rhizospheric soil. BMC. Microbiol., $8: 230$.

Parmar, N. and K. R. Dadarwall (1999). Stimulation of nitrogen fixation and induction of flavonoid like compounds by rhizobacreria. J. App. Microbiol., 86:36-44.

Pedraza, R.O., A. Ramirez-Mata, M. L. Xiqui and B. E. Baca (2004). Aromatic amino acid aminotranferase activity and 
indole-3-acetic acid production by associative nitrogenfixing bacteria. FEMS Microbiol. Letters, 233:15-21.

Remadi-Mejeda, D. F. Ayed, H. J. Khiareddine, K. Hibarn and M. EI Mahjoub (2006). Effect of some bacillus sp. Isolates on Fusarium spp . in vitro and potato tuber dry rot development in vivo. Pl. Patho. J., 5(3):283-290.

Renwick, A., R. Campbell and S. Coc (1991). Assesment of in vivo screening systems for potential biocontrol agents of Gaeumannomces graminis. Plant Pathol., 40 : 524-532.

Sakthivel, U. and B. Karthikey (2012). Isolation and characterization of plant growth promoting rhizobacteria (PGPR) from the rhizosphere of coleus forskohlii grown soil. Int. J. Rec. Sci. Res., 3(5):288- 296.

Schwyn, B. and J. B. Neilands (1987). Universal chemical assay for detection and determination of siderophores. Anal. Biochem., 160: 0-47.

Singh, N., P. Pandey, R. C. Dubey and D. K. Maheswari (2008). Biological control of root rot fungus Macrophomina phaseolina and growth enhancement of Pinus roxburghii (Sarg.) by rhizosphere competent Bacillus subtilis $\mathrm{BN}-1$, World J. Microbiol. Biotechnol., 24(9): 1669-1679.

Suslow, T.V. and M. N. Schroth (1982). rhizobacteria of sugarbeets effects of seed application and root colonization on yield fungal and bacterial. Phytopath. J.,72: 199-206.

\section{How to cite this article:}

Pandya, H.A., and Shelat, H.N. 2017. Pseudomonas aeruginosa KPSE 3 - An Endophytic PGPR for Bio Control of Potato Phytopathogens. Int.J.Curr.Microbiol.App.Sci. 6(5): 29542964. doi: https://doi.org/10.20546/ijcmas.2017.605.334 